\title{
DIALEKTIKA PENGUNGKAPAN IDENTITAS MANTAN ANGGOTA HIZBUT TAHRIR INDONESIA (HTI) KOTA MATARAM
}

\author{
Muhammad Syaoki \\ Universitas Muhammadiyah Mataram \\ e-mail: okiepluralis@gmail.com
}

\begin{abstract}
The President formally issued Perppu No / 02 / Year / 2017 on Community Organizations. Then the Ministry of Law and Human Rights officially freeze the Hizb ut-Tahrir Indonesia (HTI) community organization because it is considered against the Pancasila. The impact of the government also directly prohibits all activities related to HTI. Kemendagri forbids all Civil Servants (PNS) to become HTI members, otherwise, their status as civil servants will be revoked. Even had also circulated a list of names of HTI members who served as civil servants of the State (ASN). This study aims to see the patterns of communication made by HTI members of Mataram city after the publication of Perppu No / 02 / Tahun / 2017 and freezing of HTI SK by Kemenkumham. The results of this study indicate that the HTI of Mataram responded to the release of Perppu no / 02/2017 and HTI freezing in several ways, including no longer using HTI identity when conveying the idea of Khilafah, abolishing the name of HTI in weekly bulletins dispersed in mosques but still explore the idea of Khilafah.
\end{abstract}

\section{Key words:}

Perppu, Identity, HTI, Khilafah 


\begin{abstract}
Abstrak
Presiden secara resmi mengeluarkan Perppu No/ 02 / Tahun / 2017 tentang Organisasi masyarakat. Kemudian Kementrian Hukum dan HAM secara resmi memberlakukan organisasi masyarakat Hizbut Tahrir Indonesia (HTI) karena dinilai bertentangan dengan Pancasila. Imbasnya pemerintah juga secara langsung melarang seluruh kegiatan yang berkaitan dengan $\mathrm{HTI}$. Kemendagri melarang semua Pegawai Negeri Sipil (PNS) menjadi anggota $\mathrm{HTI}$, jika tidak statusnya sebagai PNS akan dicabut. Bahkan sempat pula beredar daftar nama-nama anggota HTI yang menjabat sebagai aparatur Sipil Negara (ASN). Penelitian ini bertujuan untuk melihat pola-pola komunikasi yang dilakukan oleh anggota $\mathrm{HTI}$ Kota Mataram pasca terbitnya Perppu No/02/tahun/2017 dan pembekuan SK HTI oleh Kemenkumham. Hasil dari penelitian ini menunjukkan bahwa HTI Kota Mataram merespon keluarnya Perppu No/02/2017 dan pembekuan HTI dengan beberapa cara, diantaranya tidak lagi menggunakan identitas $\mathrm{HTI}$ ketika menyampaikan ide tentang khilafah, meniadakan nama HTI dalam buletin mingguan yang disebar di masjid-masjid tetapi tetap mengupas ide tentang khilafah.
\end{abstract}

\title{
Kata Kunci:
}

Perppu, Identitas, HTI, Khilafah 


\section{A. Pendahuluan}

Salah satu peristiwa yang banyak menyita perhatian publik pada bulan Mei 2017 yaitu wacana pembubaran Hizbut Tahrir Indonesia (HTI) yang disampaikan langsung oleh pemerintah Indonesia melalui Mentri Kordinator Politik Hukum dan Keamanan (Menkopolhukam) Wiranto. Sejak saat itu perhatian media Massa dan masyarakat tertuju pada kelompok yang sudah ada sejak tahun 1983 ini.

Setelah berdiri selama puluhan tahun, pada era Presiden Joko Widodo pemerintah secara resmi melalui serangkaian kajian akhirnya mengeluarkan Perppu No/02/Tahun/2017 menggantikan UU No/17/Tahun/2013 yang mengatur tentang mekanisme pembubaran ormas mulai pemberian surat peringatan, pembekuan sementara, sampai dengan pembubaran melalui jalur pengadilan.

Meskipun keluarnya Perppu tersebut menimbulkan pro dan kontra di tengah masyarakat, ${ }^{67}$ namun tidak lama setelah itu pemerintah melalui Kementrian Hukum dan HAM (Kemenkumham) secara resmi membekukan ormas Hizbut Tahrir Indonesia (HTI) dan melarang seluruh anggotanya melakukan aktifitas yang berkaitan dengan HTI. Dalam Perppu tersebut juga dijelaskan bahwa mereka yang terafiliasi ormas terlarang diancam hukuman penjara minimal 6 bulan, maksimal 1 tahun.

Menteri Dalam Negeri (Mendagri) Tiahyo Kumolo pun secara tegas meminta seluruh Pegawai Negeri Sipil yang terafiliasi ke HTI untuk segera keluar dari $\mathrm{HTI}$ atau jika tidak ingin keluar dari $\mathrm{HTI}$ maka mereka diminta untuk mengundurkan diri dari Aparatur Sipil Negara (ASN). Menurutnya ini sebagai konsekuensi logis dari dibekukannya SK organisasi masyarakat Hizbut Tahrir Indonesia.

Selang beberapa hari setelah itu, beredar pula daftar nama-nama pengurus dan simpatisan HTI dari kalangan Pegawai Negeri Sipil (PNS).

\footnotetext{
${ }^{67}$ Beberapa ormas seperti Nahdlatul Ulama menyatakan dukungannya terhadap penerbitan Perppu Ormas tersebut, sementara itu beberapa ormas lain justru menganggap penerbitan Perppu sebagai bentuk kediktatoran yang dilakukan oleh pemerintah.
} 
Dokumen setebal 73 halaman itu menyebar lewat pesan elektronik ke sejumlah kalangan, termasuk ke grup-grup wartawan. Dokument tersebut menyebar secara acak, tak diketahui siapa penyebar dan pembocornya. Selain mencantumkan nama-nama 1.300an orang yang dituduh terafiliasi $\mathrm{HTI}$ dokumen tersebut juga mencantumkan alamat, pekerjaan, hubungan dengan $\mathrm{HTI}$, serta nomor ponsel.

Kekhawatiran paling besar dari beredarnya data-data tersebut ialah potensi terjadinya pengecualian, stigmatisasi, dan persekusi terhadap mereka yang diduga anggota $\mathrm{HTI}$ atau mereka yang dituduh simpatisan HTI. Jika situasi ini terjadi, negara akan sulit mengontrol serta mengendalikannya, dan itu berarti kita mengulangi kesalahankesalahan kita di masa lalu.

Beberapa kepala daerah di NTB juga menginstruksikan jajarannya yang terafiliasi dengan $\mathrm{HTI}$ untuk keluar dari HTI atau mundur dari jabatannya sebagai Aparatur Slpil Negara. ${ }^{68}$ Termasuk juga instruksi yang sama dikeluarkan oleh pimpinan-pimpinan perguruan Tinggi. Sebab selama ini kampus dinilai sebagai sarang kaderisasi $\mathrm{HTI}$, mahasiswa dan dosen yang termasuk anggota $\mathrm{HTI}$ diminta untuk segera "bertubat" dan keluar dari HTI.

Adanya larangan pemerintah terhadap ormas HTI menjadi pemicu terjadinya prasangka sosial di tengah masyarakat. Prasangka sosial sebagaimana dijelaskan W.A. Gerungan merupakan sikap atau perasaan orang-orang terhadap golongan manusia tertentu, yang berdasarkan atas perbedaan suku, agama, ras, atau kebudayaan tertentu. Ironisnya, prasangka sosial sering kali menyatakan dirinya dalam bentuk tindakan-tindakan diskriminatif terhadap golongangolongan tertentu yang dianggap berbeda dengan dirinya. Tetapi dapat menyulut aksi anarkis terhadap anggota HTI di berbagai daerah.

Faktanya, setelah keluarnya Surat Keputusan pembekuan ormas Hizbut Tahrir Indonesia di beberapa tempat kemudian muncul aksi penolakan serta pengusiran anggota $\mathrm{HTI}$ di berbagai tempat. Di

${ }^{68}$ Lihat Suara NTB 2 Agustus 2017, "Fauzan: Lombok Barat Bebas dari HTI". 
Sidoarjo sempat terjadi penutupan sekolah yang diindikasi terafiliasi dengan ormas HTI. Kejadian tersebut sempat memicu bentrokan antara warga sekitar dengan pengelola sekolah.

Pengelolaan identitas di ruang publik menjadi suatu keharusan bagi anggota $\mathrm{HTI}$. Karena identitas sebagai anggota $\mathrm{HTI}$ kerap dipersepsikan negatif oleh masyarakat pasca keluarnya Perppu No/02/Tahun/2017. Identitas, terutama identitas keagamaan merupakan sesuatu yang tingkat sensitivitasnya sangat tinggi sehingga dapat mengundang orang terjebak pada kekerasan fisik maupun mental. Taylor sebagaimana dikutip Flavius mengatakan bahwa identitas merupakan pengakuan dan tampilan penting dalam ekspresi politik kekinian, khususnya di kalangan kelompok minoritas yang mencari pengakuan.

Oleh karena itu dapat dipahami jika identitas merupakan sesuatu yang paling dijaga oleh anggota $\mathrm{HTI}$ di Kota Mataram ketika mereka berinteraksi dengan orang-orang di luar anggota mereka. Sebab paham keagamaan merupakan suatu identitas kolektif yang membutuhkan pengakuan dari pihak lain. Jika pengakuan tentang identitas ini tidak terpenuhi maka akan terjadi hubungan negatif antar individu maupun kelompok yang memiliki identitas keagamaan yang berbeda-beda tersebut.

Kehidupan sosial anggota HTI di Kota Mataram dalam posisi mereka sebagai kelompok yang mengalami diskriminasi tak ubahnya sebuah "panggung teater". Sebab keberhasilan interaksi yang mereka lakukan sedikit banyak dipengaruhi oleh bagaimana cara mereka berkomunikasi dengan orang-orang di luar kelompok mereka. Ketika mereka membuka identitas mereka pada orang yang salah maka informasi tersebut akan tersebar dan dapat mengancam eksistensi mereka di tengah masyarakat.

Ada penjelasan menarik mengenai kehidupan sosial dari Erving Goffman seorang sosiolog dari Amerika. Goffman sebagaimana dikutip Dedy Mulyana dalam bukunya Metodologi Penelitian Kualitatif: Paradigma Baru IImu Komunikasi dan IImu Sosial Lainnya mengatakan bahwa kehidupan sosial terbagi atas dua wilayah yaitu: panggung 
depan (front stage) dan panggung belakang (back stage). Panggung belakang adalah wilayah di mana seseorang menampilkan dirinya apa adanya, panggung belakang juga bisa digunakan untuk mempersiapkan perannya di panggung depan.

Sedangkan panggung depan adalah tempat di mana seseorang memainkan lakon, semata-mata untuk mengelola kesan apa yang ingin dimunculkan pada komunikan (orang lain). Intinya bahwa ketika seseorang melakukan interaksi maka ia ingin mengelola kesan yang diharapkan muncul pada orang lain tentang dirinya. Untuk mencapai tujuan tersebut menurut Goffman maka setiap orang melakukan pertunjukkan bagi orang lain.

Untuk mempresentasikan dirinya sang aktor menghadapi kesenjangan antara citra-diri yang ia inginkan dilihat orang lain, dan identitas sebenarnya, karena ia memiliki stigma (cacat), baik stigma fisik seperti buta, pincang, maupun lumpuh, ataupun stigma sosial seperti mantan narapidana, mantan anggota Partai Komunis Indonesia, ataupun stigma sebagai anggota ormas yang dilarang. Namun yang membedakannya adalah stigma fisik dapat terlihat secara langsung, sementara stigma sosial tidak terlihat. ${ }^{69}$

Persoalan-persoalan tersebutlah yang berusaha peneliti ungkap dengan menggunakan teori manajemen privasi komunikasi. Teori ini menjelaskan proses dialektis dalam sebuah hubungan sehari-hari, misalnya saat berjumpa dengan keluarga, teman kerja, masyarakat sekitar dan sebagainya. Manusia selalu menimbang situasi atau keadaan tertentu untuk memutuskan apakah ia akan membuka identitas atau justru menutupnya.

Saat komunikasi menjadi sebuah pertaruhan, maka teori ini membantu untuk menjelaskan bagaimana anggota HTI Kota Mataram mengoordinasikan atau mengatur dengan siapa mereka mesti melakukan pengungkapan identitas, serta kepada siapa pula mereka

\footnotetext{
${ }^{69}$ Dedy Mulyana, Ilmu Komunikasi: Suatu Pengantar, (Bandung: Remaja Rosdakarya 2004), 121.
} 
harus menutup identitas mereka. Ikhtiar memutuskan untuk mengungkapkan atau merahasiakan sesuatu bukanlah keputusan yang mudah dan dapat langsung diambil begitu saja, pengambilan keputusan dalam hal ini melibatkan serangkaian pertimbangan serta tindakan penyeimbangan secara terus menerus.

\section{B. Manajemen Privasi Komunikasi}

Teori Manajemen Privasi Komunikasi diperkenalkan oleh Sandra Petronio, teori ini membahas tentang proses dialektik dalam hubungan antar individu. Fokus utama dalam teori ini adalah pengelolaan ketegangan antara memilih untuk bersikap terbuka atau sebaliknya bersikap tertutup. Petronio sebagaimana dikutip Morissan mengatakan bahwa dalam sebuah hubungan antar individu seseorang akan terus menerus mengelola garis antara bersifat publik dengan membagi informasi privat atau bersifat privat dengan cara menutup informasi privat. $^{70}$

Kadang kala informasi-informasi tertentu dapat diungkapkan kepada orang lain, hal ini berarti bahwa batas antara wilayah publik dengan wilayah privat dapat ditembus. Sedangkan ketika informasi tidak dapat dibagi kepada orang lain hal ini berarti garis batas tidak dapat ditembus. Situasi-situasi tertentu mempengaruhi seseorang untuk melakukan pembukaan pribadi maupun menutupnya. Menutup informasi privat berarti mengarah pada keamanan dan otonomi yang lebih besar, sedangkan membuka informasi privat dapat meningkatkan keakraban, keintiman, namun bisa juga menimbulkan bahaya bagi diri sendiri. $^{71}$

Privasi dapat didefinisikan sebagai kemampuan seorang individu untuk menentukan kapan, bagaimana, dan seberapa luas informasi personal yang dapat disebarkan kepada orang lain. Semua orang memiliki sebuah rasa kepemilikan informasi tentang diri sendiri, dan

\footnotetext{
${ }^{70}$ Morissan, Teori Komunikasi: Individu Hingga Massa, (Jakarta: Kencana, 2013). 317.

${ }^{71} \mathrm{lbid}, 318$.
} 
mereka merasa memiliki hak untuk mengendalikan informasi tersebut. Ketika anggota $\mathrm{HTI}$ mengungkapkan informasi pribadi kepada orang lain, maka orang tersebut menjadi pemilik kedua dari informasi tersebut, dan kepemilikan bersama itu memiliki hak-hak dan kewajibannya masing-masing. ${ }^{72}$

Teori manajemen privasi komunikasi menawarkan cara-cara untuk mengidentifikasi batasan privasi yang dikoordinasikan antara individuindividu. Untuk mencapai tujuan-tujuan tersebut, Petronio mengajukan lima asumsi dasar yaitu: informasi privat, batasan privat, kontrol dan kepemilikan, sistem manajemen berdasarkan aturan, dan dialektika manajemen.

a. Informasi Privat

Asumsi ini merujuk pada cara berpikir mengenai pembukaan atau pengungkapan informasi privat. Banyak peneliti telah mengombinasikan pembukaan diri dengan keintiman seakan keduanya merupakan hal yang ekuivalen walaupun dua hal ini merupakan dua konsep yang berbeda. Petronio berpendapat bahwa:

"Keintiman (intimacy) adalah perasaan atau keadaan mengetahui seseorang dengan cara mendalam dalam ciri-ciri fisik, psikologi, emosional, dan perilaku karena orang ini penting dalam kehidupan seseorang. Pembukaan pribadi, sebaliknya, tertarik dengan proses bercerita dan merefleksikan isi dari informasi yang privat mengenai orang lain dan kita" West dan Turner ${ }^{73}$

West dan Turner mengatakan bahwa "apa yang membuat suatu hal privat adalah sebagian besar karena pentingnya hal tersebut bagi konsepsi kita akan diri kita sendiri dan bagi hubungan kita dengan orang lain". Orang mendefinisikan informasi privat sebagai informasi

\footnotetext{
${ }^{72}$ Littlejohn, W. Stephen dan Karen A. Foss, Teori Komunikasi diterjemahkan oleh M Yusuf Hamdan dari Theories of Human Communication, (Jakarta: Salemba Humanika. 2014): 307.

${ }^{73}$ West, Richard and Lynn H.G.Turner, 2012, Introducing Comunication Theory: Analysis and Aplication, (New York: McGraw Hill, 2010), 225.
} 
tentang hal-hal yang sangat berarti bagi mereka. Dalam penelitian ini yang dimaksud dengan informasi privat yaitu segala informasi tentang diri mereka yang jika diungkapkan ke publik atau orang di luar kelompok mereka maka akan mengundang reaksi dalam bentuk diskriminasi atau perlakuan-perlakuan buruk lainnya.

b. Batasan Privat

Manajemen privasi komunikasi bergantung terhadap metafora batasan dalam menjelaskan bahwa ada garis antara bersifat publik serta bersikap privat. Pada satu sisi batasan ini, seseorang menyimpan informasi privat untuk diri mereka sendiri. Pada sisi yang lain, seseorang membuka informasi privat kepada orang lain dalam relasi sosial dengan mereka. Ketika informasi privat dibagikan batasan di sekitarnya disebut batasan kolektif (collective boundary), sebab informasi tersebut menjadi milik hubungan yang ada. Ketika informasi privat disimpan oleh seorang individu dan tidak dibuka, maka batasannya disebut batasan personal (personal boundany). ${ }^{74}$

Menurut Petronio, individu-individu yang terlibat dalam hubungan terus mengatur batasan-batasan antara apa yang umum dan pribadi, antara perasaan-perasaan yang ingin mereka bagi. Kadang-kadang batasannya dapat ditembus, yang berarti bahwa informasi tertentu dapat diungkapkan; namun di saat yang lain, batasan tersebut tidak dapat ditembus yang berarti informasi tidak pernah dibagi. Mempertahankan batasan tertutup dapat memberikan otonomi dan keamanan yang lebih kuat, sedangkan pembukaan batasan dapat memberikan kedekatan dan pembagian yang lebih besar, tetapi juga kelemahan yang lebih besar.

Dalam penelitian ini batasan privat yang dimaksud adalah garis pembatas antara informasi yang dianggap sebagai privasi dan bukan privasi oleh anggota HTI. Dalam mengelola batasan tersebut anggota HTI terlibat dalam pilihan membuka maupun menutup batasannya. Ketika batasan dibuka maka informasi tersebut berubah dari informasi

\footnotetext{
${ }^{74} /$ bid., 225.
} 
privat menjadi informasi publik. Sebaliknya, ketika batasan tersebut ditutup maka informasi tersebut tetap menjadi informasi privat.

c. Kontrol dan Kepemilikan

Asumsi ini bergantung pada ide bahwa orang merasa mereka punya informasi privat mengenai diri mereka sendiri. Sebagai pemilik informasi, mereka percaya bahwa mereka harus ada dalam posisi untuk mengontrol siapa saja (jika memang ada) yang boleh mengakses informasi ini. Kontrol dan kepemilikan di sini terkait dengan otoritas yang dimiliki oleh Anggota HTI terkait dengan informasi privat mereka. $^{75}$

d. Sistem Manajemen Berdasarkan Aturan

Sistem ini merupakan kerangka untuk memahami keputusan yang dibuat seseorang mengenai informasi privat. Sistem ini memungkinkan pengelolaan dalam level individu maupun kolektif yang terdiri atas tiga proses yaitu: karakteristik aturan privasi, koordinasi batasan, dan turbulensi batasan.

\section{Dialektika Manajemen}

Asumsi ini berfokus pada ketegangan-ketegangan antara keinginan untuk mengungkapkan informasi privat atau keinginan untuk menutupinya. Tesis dasar dari teori manajemen privasi menurut Petronio didasarkan pada kesatuan dialektika merujuk pada keteganganketegangan yang dialami seseorang sebagai akibat dari kontradiksi dan oposisi. Dalam hal ini dialektika manajemen berkaitan dengan keinginan Anggota HTI untuk mengungkapkan informasi privat mereka di satu sisi, namun di sisi lain mereka juga ingin menutupinya. ${ }^{76}$

\section{Dialektika Pengungkapan Identitas Anggota HTI}

Dalam penelitian ini peneliti melakukan wawancara dengan salah seorang anggota HTI Kota Mataram bernama Dodi Supriadi. Dodi

\footnotetext{
${ }^{75} / \mathrm{bid} ., 226$.

76/bid., 227.
} 
merupakan salah seorang mahasiswa salah satu perguruan tinggi swasta di Kota Mataram. la berasal dari Kabupaten Sumbawa namun sudah lama menetap di Kota Mataram. Dodi masuk sebagai anggota HTI sejak tahun 2012 ia mengenal HTI ketika masih di Batam namun pada tahun 2015 Dodi pindah ke Mataram dan bergabung dengan HTI kota Mataram. ${ }^{77}$

Sejak aktif di HTI Kota Mataram Dodi didaulat menjadi ketua Aliansi Persaudaraan Muslim (APM) NTB. Dodi juga terlibat langsung dalam beberapa Aksi Bela Islam yang dilakukan di Jakarta pada medio tahun 2016. Dalam aksi tersebut ia membawa atribut HTI, ia juga beberapa kali memposting tulisan yang mengajak ummat Islam untuk menjalankan sistem khilafah.

Hal ini terlihat dalam salah satu postingannya pada 13 September 2017 melalui akunnya Haarisul Ummah. Dalam postingan tersebut Dodi mengecam keras aksi kekerasan yang dilakukan oleh militer Myanmar terhadap Muslim Rohingya, Dodi mendesak pemerintah mengirimkan tentara ke Myanmar untuk membantu Muslim Rohingya. la juga tidak lupa menyampaaikan bahwa khilafah merupakan solusi atas krisi yang terjadi di Myanmar.

Selain itu banyak juga postingan-postingan lain yang mengkritisi pemerintah terutama terkait dengan pembekuan HTI yang mereka anggap sebagai sebuah bentuk kezhaliman terhadap ummat Islam. Termasuk juga mengkritisi sikap pemerintah ketika Presiden Amerika Donald Trump akan memindahkan Kedutaan Besarnya ke Jerussalem.

Salah satu bentuk dialektika pengungkapan identitas yang dilakukan oleh anggota HTI Kota Mataram ialah dengan merubah nama buletin yang dulu namanya Huijah dan mencatumkan nama Hizbuttahrir Indonesia, namun setelah Perppu keluar buletin tersebut berganti nama menjadi kaffah. Perubahan nama tersebut diakui sebagai salah satu cara beradaptasi agar tetap dapat menyampaikan ide tentang khilafah setelah keluarnya Perppu. ${ }^{78}$

\footnotetext{
${ }^{77}$ Wawancara dengan Dodi Supriadi 6 Desember 2017.

${ }^{78}$ Wawancara dengan Dodi Supriadi 6 Desember 2017.
} 
Buletin yang dibagikan secara cuma-cuma kepada semua jamaah setiap selesai shalat jumat. Buletin tersebut berisi kritik terhadap sistem demokrasi dan ajakan menjalankan sistem khilafah. Hal itu terbukti dalam bulletin Edisi 018/08 Desember 2017 yang peneiliti terima setelah melaksanakan shalat Jumat di Masjid Istiqlal Pagesangan. Buletin tersebut mengupas tentang Reuni Aksi 212 yang dilakukan di Jakarta.

Dalam pandangan HTI reuni 212 merupakan salah satu bukti bahwa ummat Islam sesungguhnya memiliki potensi yang sangat luar biasa, hanya saja potensi tersebut belum bisa dijadikan kekuatan karena ummat Islam masih terkotak-kotak dalam berbagai gerakan. Salah satu upaya untuk menyatukan ummat Islam di Indonesia yaitu dengan kembali menyatu dalam satu payung yang bernama khilafah.

Bagi anggota HTI menyampaikan ide tentang khilafah merupakan kewajiban ummat Islam sebab ide tentang khilafah adalah bagian dari dakwah. Oleh karena itu tanpa menggunakan identitas HTI sekalipun, gagasan tentang khilafah akan tetap disampaikan kepada ummat Islam.

Anggota HTI Kota Mataram berusaha membangun batasan informasi mengenai identitas mereka dengan cara menutup akses informasi dari selain anggota $\mathrm{HTI}$. Hal ini peneliti temui ketika mencoba mencari anggota $\mathrm{HTI}$ di Kota Mataram. Beberapa di antara mereka mengaku bukan anggota HTI lagi meskipun dalam pantauan peneliti mereka masih tetap aktif menyampaikan ide tentang khilafah.

Salah satu kegiatan yang dibuat pasca dibekukannya HTI yaitu mebentuk komunitas Yuk Hijrah. Komunitas ini bertujuan untuk mewadahi orang-orang yang ingin kembali kepada kebaikan serta meninggalkan kebiasaan-kebiasaan buruk yang dulu sering mereka lakukan. Kegiatan ini menyasar para pemuda yang memiliki keresahan spiritual.

Terjadi proses dialektis dalam diri anggota $\mathrm{HTI}$, di satu sisi mereka ingin sekali menyampaikan ide tentang khilafah secara terbuka kepada ummat Islam, namun di sisi lain ada aturan yang melarang mereka 
melakukan aktifitas dalam bentuk apapun sebab secara hukum, organisasi mereka sudah dibubarkan.

\section{E. Kesimpulan}

HTI Kota Mataram merespon terbitnya Perppu 02/2017 dengan berbagai cara diantaranya membatasi pihak-pihak yang dapat mengakses informasi privat mereka terkait HTI. Menyampaikan ide tentang khilafah kepada publik melalui forum-forum diskusi, postingan di media sosial, maupun buletin mingguan meskipun tidak lagi menggunakan atribut $\mathrm{HTI}$.

Anggota HTI Kota Mataram juga melakukan kontrol atas kepemilikan informasi privat mereka, sehingga mereka dapat menentukan siapa saja yang bisa masuk dan tidak ke dalam batasan informasi privat. Upaya ini dilakukan dalam rangka merespon pembekuan organisasi HTI dan pelarangan seluruh aktifitas $\mathrm{HTI}$ oleh pemerintah. 


\section{Daftar Pustaka}

Creswell, W. John, Research Design: Pendekatan Kualitatif, Kuantitatif, dan Mixed diteriemahkan oleh Achmad Fawaid dari Research Design: Qualitative, Quantitative, and Mlxed Methods Approaches, (Yogyakarta: Pustaka Pelajar, 2014)

Jamhari dan Jajang Jahroni (ed), Gerakan Salafi Radikal di Indonesia, (Jakarta, Raja Grafindo, 2004).

Littlejohn, W. Stephen dan Karen A. Foss, Teori Komunikasi diteriemahkan oleh M Yusuf Hamdan dari Theories of Human Communication, (Jakarta: Salemba Humanika, 2014).

Morissan, Teori Komunikasi: Individu Hingga Massa, (Jakarta: Kencana, 2013).

Mulyana, Deddy, I/mu Komunikasi: Suatu Pengantar, (Bandung: Remaja Rosdakarya, 2003).

Petronio, Sandra, Boundaries of Privacy: Dialectics of Disclosure, (New York: State University of New York Press, 2002)

Sugiyono, Metode Penelitian Kuantitatif, Kualitatif dan R\&D, (Bandung, Alfabeta, 2008)

Wahid, Abdurrahman (ed), 2009, Ilusi Negara Islam: Ekspansi Gerakan Transnasional di Indonesia, Jakarta, The Wahid Institute.

West, Richard and Lynn H.G.Turner, 2012, Introducing Comunication Theory: Analysis and Aplication, New York: McGraw Hill.

https://mataramnews.co.id/nusa-tenggara-barat/item/7572-ini-

pernyataan-sikap-gp-ansor-ntb-terkait-kegiatan-hti

http://www.postkotantb.com/2017/07/rektor-uin-mataram-ancam-

keluarkan.ht

Wawancara Dodi Supriadi Anggota HTI kota Mataram

Departemen Agama R.I. Al-Qur'an dan Terjemahnya. Semarang: Karya Toha Putra, 1995. 
Elmina Martha, Aroma, Hukum KDRT Kekerasan dalam Rumah Tangga. Yogyakarta: Aswaja Pressindo, 2015.

Freedman Lisa, Wife Assault, dalam Connie Guberman et al. (ed) Safe Place, Violence Againts Women and Children. Tronto, Ontario: Womens Press, 11985

Hadiati Soeroso, Moerti, Kekerasan dalam Rumah Tangga dalam Perspektif Yuridis-Viktimologis, Jakarta: Sinar Grafika, 2012

Morris Allison Women, Crime and Criminal Justice, USA: Basil Blackwell Inc, 1987

Mufidah, Psikologi Keluarga Islam, Cet. I; Malang: UIN Malang Press, 2008

Muhammad bin Isa Abu at-Turmudzi, Sunan Turmudzi, Juz 3; Beirut: Dar llya' Turats, it.

Nurdjunaida Sri, Sekilas Kekerasan Terhadap Perempuan, Jakarta: tp, 2008

UU RI Tentang Penghapusan Kekerasan dalam Rumah Tangga Nomor 23 Tahun 2004

Wadud Amina, Qur'an Menurut Perempuan, Mebaca Kembali Kitab Suci dengan Semangat Keadilan, Alih bahasa. Abdullah Ali. Jakarta: Serambi 